\title{
PENGELOLAAN BENGKEL PRAKTIK SMK TEKNIK PEMESINAN DI KABUPATEN PURWOREJO
}

\author{
Purwanto $^{1)}$ dan Thomas Sukardi ${ }^{2)}$ \\ ${ }^{1)}$ SMK YEPEKA Purworejo; ${ }^{2)}$ Universitas Negeri Yogyakarta \\ pur24_pur24@yahoo.co.id; thomkar234@yahoo.co.id
}

\begin{abstract}
This study aims to know the quality of: (1) planning, (2) organizing, (3) actuating, and (4) controlling of mechanical engineering workshop management at SMK in Purworejo Regency. This study is a quantitative study with survey method. The respondents of this study were the practical lesson teachers of mechanical engineering SMK in Purworejo Regency. The data collection techniques were questionnaire, interview, and observation. The data analysis technique used was descriptive statistics. The results showed that: (1) the planning has a good quality with a mean of 2.961 ; (2) the organizing has a good quality with a mean of 2.947; (3) the actuating has a good quality with a mean of 3.207; and (4) the controlling has a good quality with a mean of 2.874.
\end{abstract}

Keywords: Management, Mechanical Engineering Workshop

\begin{abstract}
ABSTRAK
Penelitian ini bertujuan untuk mengetahui kualitas: (1) perencanaan, (2) pengorganisasian, (3) pelaksanaan, dan (4) pengawasan pada pengelolaan bengkel praktik SMK Teknik Pemesinan di Kabupaten Purworejo. Penelitian ini adalah penelitian kuantitatif dengan metode penelitian survei. Responden pada penelitian ini adalah guru praktik SMK Teknik Pemesinan di Kabupaten Purworejo. Teknik pengumpulan data yang digunakan adalah: kuesioner, wawancara, dan observasi. Teknik analisis data yang digunakan adalah statistik deskriptif. Hasil penelitian menunjukkan bahwa: (1) perencanaan mempunyai kualitas baik dengan mean 2,961; (2) pengorganisasian mempunyai kualitas baik dengan mean 2,947; (3) pelaksanaan mempunyai kualitas baik dengan mean 3,207; dan (4) pengawasan mempunyai kualitas baik dengan mean 2,874.
\end{abstract}

Kata Kunci: Pengelolaan, Bengkel Praktik Teknik Pemesinan.

\section{PENDAHULUAN}

Sekolah Menengah Kejuruan (SMK) merupakan lembaga pendidikan untuk menciptakan sumber daya manusia yang memiliki keterampilan sesuai dengan bidang keahlian tertentu. Jenjang pendidikan SMK bertujuan untuk mengembangkan keterampilan siswa menjadi calon tenaga kerja siap kerja. Mengacu pada hal tersebut, maka kegiatan praktik di bengkel praktik mempunyai peranan yang sangat penting dalam mengembangkan keterampilan siswa sebagai bekal untuk bekerja di dunia industri.

Bengkel praktik SMK khususnya pada kompetensi keahlian Teknik Pemesinan tertuang dalam Permendiknas Nomor 40 Tahun
2008 tentang standar sarana dan prasarana untuk Sekolah Menengah Kejuruan/Madrasah Aliyah Kejuruan. Bengkel praktik pemesinan sebagai ruang pembelajaran praktik kompetensi keahlian Teknik Pemesinan yang terdiri dari: area kerja bangku berkapasitas 8 siswa, ruang pengukuran dan pengujian logam berkapasitas 4 siswa, area kerja mesin bubut berkapasitas 8 siswa, area kerja mesin frais berkapasitas 4 siswa, area kerja mesin gerinda berkapasitas 4 siswa, dan ruang kerja pengepasan berkapasitas 4 siswa. Sarana dan prasarana bengkel praktik Teknik Pemesinan harus dikelola dengan baik untuk memfasilitasi kebutuhan siswa secara maksimal dalam mengembangkan keterampilan di bidang pemesinan. 
Terry (1974:4) menyatakan bahwa proses manajemen tercermin pada gambar berikut:

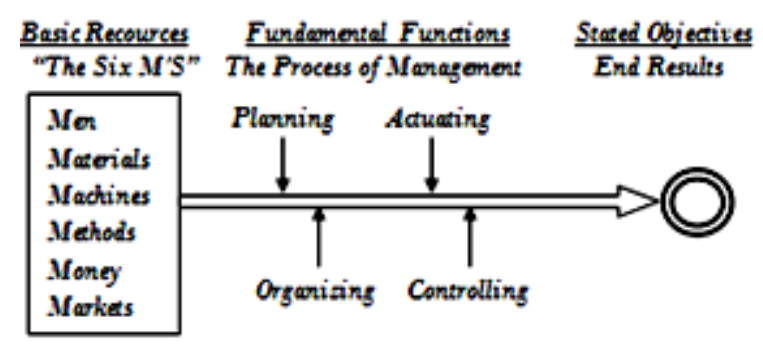

Gambar 1. Proses Manajemen

Manajemen merupakan suatu proses yang terdiri dari perencanaan (planning), pengorganisasian (organizing), pelaksanaan (actuating), dan pengawasan (controlling) untuk mencapai tujuan yang telah ditetapkan.

Purworejo dideklarasikan sebagai kabupaten vokasi pada tanggal 26 Juni 2012. Predikat sebagai kabupaten vokasi diharapkan dapat menciptakan sumber daya manusia lulusan SMK yang lebih kompetitif, akuntabel, terampil, dan siap memasuki dunia kerja sehingga dapat menekan angka kemiskinan di Kabupaten Purworejo (http://purworejokab.go .id/news/seputarpendidikan/1791-purworejo deklarasikan-sebagai-kabupaten-vokasi).

Dengan demikian, predikat sebagai kabupaten vokasi yang disandang oleh Purworejo membuat SMK di Kabupaten Purworejo dituntut untuk meningkatkan kualitas lulusan SMK dalam rangka menekan angka pengangguran.

SMK kompetensi keahlian Teknik Pemesinan di Kabupaten Purworejo terdapat tujuh sekolah yaitu: SMK N 1 Purworejo, SMK Pembaharuan Purworejo, SMK TKM Teknik Purworejo, SMK Pancasila 1 Kutoarjo, SMK PN 2 Purworejo, SMK YPT Purworejo, dan SMK Institut Indonesia Kutoarjo. Hasil observasi menunjukkan bahwa: area kerja bangku seharusnya berkapasitas 8 siswa masih ditemukan kapasitas kurang dari 8 siswa, ruang pengukuran dan pengujian logam seharusnya berkapasitas 4 siswa masih ditemukan kapasitas kurang dari 4 siswa bahkan enam dari tujuh
SMK tidak mempunyai alat pengujian logam, mesin bubut seharusnya berjumlah 8 mesin masih ditemukan yang jumlahnya kurang dari 8 mesin, mesin frais seharusnya berjumlah 4 mesin masih ditemukan yang jumlahnya kurang dari 4 mesin, mesin gerinda seharusnya berjumlah 4 mesin masih ditemukan yang jumlahnya kurang dari 4 mesin, ruang pengepasan seharusnya berkapasitas 4 siswa tetapi tidak ada bengkel praktik teknik pemesinan yang dilengkapi dengan ruang pengepasan.

Berdasarkan hasil observasi menunjukkan bahwa tidak semua mesin dalam kondisi baik, akan tetapi masih ditemukan mesin dalam kondisi kurang presisi dan rusak sedang. Mesin yang kurang presisi dan rusak sedang adalah mesin bubut. Kondisi mesin yang kurang presisi dan rusak sedang terjadi karena pemeliharaan mesin tidak dilaksanakan secara teratur dan tindakan pemeliharaan hanya dilaksanakan ketika terjadi kelainan ataupun kerusakan pada mesin. Fenomena pengelolaan bengkel praktik SMK Teknik Pemesinan di Kabupaten Purworejo belum maksimal untuk memfasilitasi kegiatan praktik siswa.

Dengan adanya permasalahan pengelolaan bengkel praktik SMK Teknik Pemesinan di Kabupaten Purworejo, maka peneliti akan melakukan penelitian mengenai pengelolaan bengkel praktik yang meliputi: (1) perencanaan, (2) pengorganisasian,(3) pelaksanaan, dan (4) pengawasan pada SMK Teknik Pemesinan di Kabupaten Purworejo untuk memaparkan kondisi pengelolaan bengkel praktik SMK Teknik Pemesinan. Hasil penelitian diharapkan dapat memberikan kontribusi dalam meningkatkan kualitas pengelolaan bengkel praktik SMK Teknik Pemesinan. Dengan pengelolaan bengkel praktik yang baik, maka bengkel praktik SMK Teknik Pemesinan di Kabupaten Purworejo dapat memfasilitasi kebutuhan siswa secara maksimal untuk mengembangkan keterampilan sebagai bekal bekerja di dunia industri. 


\section{Pendidikan Ke juruan}

Pendidikan kejuruan merupakan pendidikan yang mempersiapkan peserta didik untuk dapat bekerja dalam bidang tertentu. Hal ini sesuai dengan pernyataan Pavlova (2009:7) yang menyatakan bahwa: “...direct preparation for work was the main goal of vocational education". Tujuan utama pendidikan kejuruan adalah mempersiapkan peserta didik secara langsung untuk bekerja. Pendidikan kejuruan tidak hanya membekali peserta didik dengan pengetahuan, akan tetapi juga keterampilan dalam bidang keahlian tertentu.

Pendidikan kejuruan membekali siswa dengan keterampilan sebagai bekal untuk bekerja pada bidang tertentu. Wilson (2010: 90) mengatakan bahwa: “...vocational education students view their classroom as beneficial. They felt that this type of education was particularly helpful in gaining real job skills needed to support themselves after high school". Pendidikan kejuruan mempunyai keunggulan yaitu siswa mendapatkan keterampilan kerja nyata yang diperlukan untuk mendukung siswa setelah lulus dari jenjang pendidikan kejuruan.

Firdausi dan Barnawi (2012: 22) mengatakan bahwa tujuan SMK adalah menyiapkan siswa sesuai dengan bidang keahlian tertentu untuk: (1) memasuki lapangan kerja serta dapat mengembangkan sikap profesional dalam lingkup keahliannya; (2) mampu memilih karier, mampu berkompetisi dan mampu mengembangkan diri dalam lingkup keahlian yang dipilih dan ditekuni; (3) menjadi tenaga kerja tingkat menengah untuk mengisi kebutuhan dunia usaha dan industri. SMK hendaknya mempunyai acuan yang jelas dalam menyelenggarakan pendidikan kejuruan, sehingga lulusan SMK mudah diserap oleh pasar untuk mengisi kekosongan lowongan kerja di dunia industri.

Pembelajaran di SMK terdiri dari dua jenis yaitu pembelajaran teori dan pembelajaran praktik. Pembelajaran teori diselenggarakan di ruang kelas sedangkan pembelajaran praktik diselenggarakan di bengkel praktik. Aurigemma, dkk (2013: 138) mengatakan bahwa: "if we can better understand how knowledge and skills are deployed in realworld engineering problem solving, we can better identify design principles to assist us in developing educational models that achieve fidelity between the two sites of the classroom and the work place whether it be a lab or industry". Pengetahuan dan keterampilan teknik lebih mudah dipahami dengan mengembangkan model pendidikan yang memadukan antara dua lokasi yaitu kelas dan tempat kerja baik itu bengkel praktik atau industri.

Rochadi (2011: 2-3) menyampaikan bahwa bengkel sekolah berfungsi sebagai tempat untuk alih kompetensi (transfering competense). Proses alih kompetensi dapat digambarkan sebagai berikut:

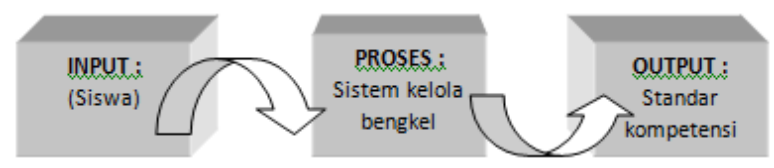

Gambar 2. Fungsi Bengkel Sekolah

(1) siswa sebagai input merupakan pelanggan yang harus dilayani sedemikian rupa sehingga apa yang menjadi harapan memperoleh kompetensi dari bidangnya dapat terpenuhi; (2) untuk dapat memperoleh kompetensi yang diharapkan, siswa dikembangkan di bengkel sekolah. Keberhasilan alih kompetensi siswa sangat ditentukan oleh bagaimana cara pengelolaan bengkel sekolah; (3) sasaran akhir dari pengembangan siswa adalah untuk mencapai kompetensi yaitu terdiri dari: keilmuan (knowledge), keterampilan (skills), maupun mental kepribadian (attitude). Sedemikian pentingnya peranan bengkel praktik yang digunakan sebagai tempat alih kompetensi (transfering competense), maka fasilitas bengkel praktik harus dikelola dengan baik dalam rangka pengembangan siswa untuk mencapai kompetensi yang diharapkan. 


\section{Bengkel Praktik}

SMK identik dengan laboratorium ataupun bengkel praktik yang digunakan sebagai sarana dan tempat pelatihan keterampilan siswa. Singer, dkk (2006: 31) mengatakan bahwa: "laboratory experiences provide opportunities for students to interact directly with the material world (or with data drawn from the material world), using the tools, data collection techniques, models, and theories of science". Laboratorium digunakan sebagai tempat untuk memberikan kesempatan bagi siswa berinteraksi langsung dengan dunia material, menggunakan alat, teknik pengumpulan data, model, dan teori-teori ilmu pengetahuan.

Laboratorium sebagai tempat kegiatan pada pendidikan kejuruan terbagi dalam beberapa jenis menurut spesifikasinya. Brown (1979: 17-18) membagi laboratorium teknik kejuruan menjadi tiga jenis yakni: (1) laboratorium unit (unit laboratory) digunakan untuk kegiatan praktik yang spesifik atau kegiatan praktik khusus; (2) laboratorium unit umum (general unit laboratory) digunakan untuk kegiatan praktik yang lebih besar dan lebih komprehensif dibandingkan laboratorium unit; dan (3) laboratorium umum (general laboratory) didesain untuk pekerjaan yang lebih luas.

Bengkel berfungsi sebagai ruang pembelajaran praktik di SMK. Hal ini sesuai dengan pernyataan CEFP (1969: 79) yang menyatakan bahwa: "several related kinds of learning spaces that are often referred to as shops are found in comprehencive secondary schools, vocational high schools, technical schools and some institutions of higher education. these are generally used for the action learning activities associated with certain kinds of general education curriculums and particular vocational preparation programs". Ruang pembelajaran yang disebut sebagai bengkel sering dijumpai di Sekolah Menengah Kejuruan. Bengkel digunakan untuk kegiatan pembelajaran praktik berdasarkan kurikulum pendidikan umum dan kejuruan.
Bengkel praktik Teknik Pemesinan harus mempunyai fasilitas yang lengkap untuk mendukung secara optimal kegiatan pembelajaran praktik. Pada Permendiknas Nomor 40 Tahun 2008 dijelaskan bahwa ruang praktik kompetensi keahlian Teknik Pemesinan berfungsi sebagai tempat berlangsungnya kegiatan pembelajaran: pekerjaan logam dasar; pengukuran dan pengujian logam; membubut lurus, bertingkat, tirus, ulir luar dan dalam; memfrais lurus, bertingkat, roda gigi; menggerinda alat; dan pengepasan atau pemasangan komponen. Bengkel pemesinan yang mempunyai fasilitas lengkap dengan kondisi baik, maka dapat memberikan pelayanan maksimal dalam rangka pencapaian kompetensi siswa di bidang pemesinan.

\section{Pengelolaan Bengkel Praktik}

Istilah pengelolaan merupakan sinonim dari manajemen. Manajemen menurut Terry (1974: 4) adalah: "management is a distinct process consisting of planning, organizing, actuating, and controlling, performed to determine and accomplish stated objectives by the use of human beings and other resources". Manajemen merupakan suatu proses yang terdiri dari perencanaan, pengorganisasian, pelaksanaan, dan pengawasan yang dilakukan untuk menentukan dan mencapai sasaran yang telah ditetapkan melalui pemanfaatan sumber daya manusia dan sumber daya lainnya.

Handoko (2003: 79-80) mengatakan bahwa kegiatan perencanaan pada dasarnya terdiri dari empat tahap. Adapun mekanisme proses perencanaan tertuang pada gambar berikut ini:

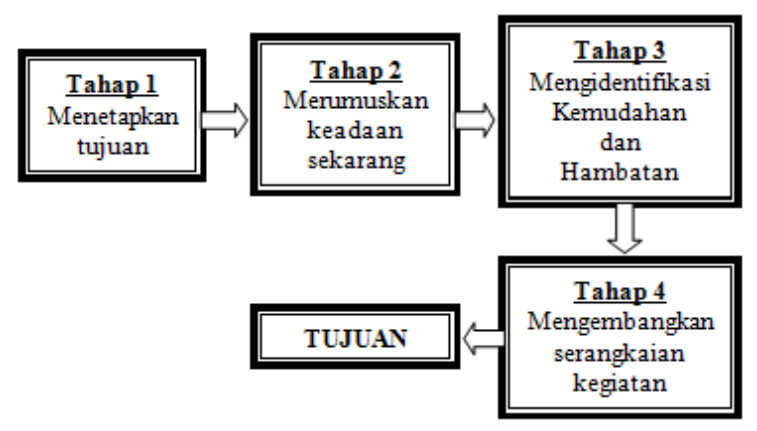

Gambar 3. Tahapan Proses Perencanaan 
Proses perencanaan terdiri dari empat tahap yaitu: menetapkan tujuan atau serangkaian kegiatan, merumusan keadaan saat ini, mengidentifikasi segala kemudahan dan hambatan, serta mengembangkan rencana atau serangkaian kegiatan untuk mencapai tujuan. Suatu perencanaan yang baik terdiri dari enam unsur pertanyaan yaitu apa, mengapa, dimana, kapan, siapa, dan bagaimana. Manullang (2006: 41) menyatakan bahwa suatu perencanaan berisi penjelasan tentang: (1) perincian kegiatan yang dibutuhkan dalam kaitannya dengan faktor produksi yakni sarana dan prasarana yang diperlukan untuk melaksanakan kegiatan dapat terpenuhi; (2) alasan kegiatan tersebut harus dilaksanakan dan tujuan yang telah ditentukan harus dicapai; (3) lokasi fisik setiap kegiatan harus mempunyai segala fasilitas yang dibutuhkan untuk mengerjakan suatu pekerjaan; (4) waktu pelaksanaan pekerjaan baik untuk tiap-tiap bagian pekerjaan maupun seluruh pekerjaan; (5) petugas yang akan mengerjakan baik mengenai kuantitas maupun kualitas yakni kualifikasi pegawai, keahlian, dan pengalaman; (6) teknik atau prosedur mengerjakan suatu pekerjaan. Unsur perencanaan pada proses manajemen terdiri dari rincian kegiatan, alasan pelaksanaan kegiatan, lokasi kegiatan beserta fasilitas yang dibutuhkan, waktu pelaksanaan, petugas, dan prosedur pengerjaan.

Suatu organisasi harus mempunyai pembagian tugas yang jelas untuk mencapai tujuan. Terry (1986: 234) mengatakan bahwa sebuah organisasi formal mempunyai empat komponen dasar yaitu: (1) pekerjaan yang dibagi-bagi; (2) orang-orang yang ditugaskan untuk melaksanakan pekerjaan yang dibagi-bagi tersebut; (3) lingkungan dimana pekerjaan dilaksanakan; (4) hubungan antara orang-orang didalam kelompok kerja dan begitu pula hubungan kelompok kerja satu dengan yang lain. Proses pengorganisasian pada suatu organisasi formal berisi tentang pembagian beban kerja, susunan personel organisasi yang melaksanakan pekerjaan, lingkungan dan hubungan personel organisasi dalam me- laksanakan pekerjaan. Pengorganisasian merupakan faktor penting dalam merancang struktur formal, mengelompokkan, mengatur, dan membagi tugas atau pekerjaan anggota organisasi. Handoko (2003: 168-169) mengatakan bahwa prosedur proses pengorganisasian dapat dilakukan dengan tiga langkah yaitu: (1) perincian seluruh pekerjaan yang harus dilakukan untuk mencapai tujuan organisasi; (2) pembagian beban pekerjaan total menjadi kegiatan-kegiatan yang dapat dilakukan oleh satu orang. Pembagian kerja sebaiknya tidak terlalu berat dan jangan terlalu ringan; (3) pengadaan dan pengembangan suatu mekanismedilakukan untuk mengkoordinasikan pekerjaan para anggota organisasi menjadi kesatuan yang terpadu dan harmonis. Proses pengorganisasian berfungsi untuk merinci seluruh pekerjaan, membagi beban pekerjaan, dan mengembangkan mekanisme kerja untuk mempermudah koordinasi antar anggota organisasi.

Pelaksanaan merupakan tahapan ketiga pada proses manajemen. Terry (1974: 435) mengatakan bahwa: "actuating is getting all the members of the group to want to achieve and strive to achieve mutual objectives because they want to achieve them". Pelaksanaan merupakan upaya mempengaruhi semua anggota kelompok untuk ingin mencapai tujuan organisasi dan berusaha untuk mencapai tujuan bersama karena mereka ingin mencapainya. Proses pelaksanaan (actuating) pada manajemen mencakup: komunikasi, pemberian motivasi, dan kepemimpinan. Komunikasi mempunyai peranan penting pada suatu organisasi dalam mencapai tujuan yang telah ditetapkan. Hasibuan (2007:193) mengatakan fungsi komunikasi antara lain: (1) instructive, artinya komunikasi dalam hal ini berfungsi untuk memberikan perintah dari atasan kepada bawahannya; (2) evaluative, artinya komunikasi berfungsi untuk menyampaikan laporan dari bawahan kepada atasannya; (3) informative, adalah komunikasi dalam hal ini berfungsi untuk menyampaikan informasi, berita, dan pesan-pesan lainnya; (4) influencing, artinya 
komunikasi dalam hal ini berfungsi untuk memberikan saran-saran, nasihat-nasihat dari seseorang kepada orang lain. Handoko (2003: 252-255) mengungkapkan bahwa motivasi dalam organisasi mencakup model sebagai berikut: (1) model tradisional yaitu upaya motivasi kepada para anggota organisasi dengan penghargaan dalam bentuk uang;

model hubungan manusiawi yaitu upaya motivasi kepada anggota organisasi dengan memberi perhatian, memberi kebebasan untuk membuat keputusan dalam pekerjaan, dan membuat anggota organisasi merasa berguna dan penting; (3) model sumber daya manusia yaitu upaya motivasi kepada anggota organisasi dengan memberi tanggung jawab yang lebih besar untuk membuat keputusan dan pelaksanaan tugas untuk meraih prestasi kerja yang baik. Menurut Terry (1974: 459) seorang pemimpin harus mampu menerapkan jiwa kepemimpinan berikut: "(1) inspires the employee;(2) accomplishes work and develops the employee; (3) shows employee how to do his job; (4) assumes obligations; (5) fixes the breakdown for loss in production or sales". Seorang pemimpin harus dapat memberikan inspirasi kepada bawahan, menyelesaikan pekerjaan dan mengembangkan bawahan, menunjukkan bagaimana cara melaksanakan pekerjaan, bertangung jawab, dan memperbaiki kegagalan dalam upaya mencapai tujuan.

Menurut Manullang (2006: 176-180) proses pengawasan terdiri dari: (1) waktu pelaksanaan pengawasan dilaksanakan melalui pengawasan preventif sebagai tindakan pencegahan dan pengawasan represif yakni tindakan pengawasan setelah kegiatan diselesaikan; (2) objek yang dilihat pada proses pengawasan antara lain aspek produksi, kondisi keuangan, waktu pelaksanaan kegiatan, dan sumber daya manusia; (3) subjek yang melaksanakan pengawasan adalah pengawas intern yakni pengawasan dari atasan dan pengawasan ekstern yakni pengawasan dari luar organisasi; (4) proses pengawasan kegiatan organisasi dapat dilakukan dengan cara peninjauan pribadi secara langsung, laporan lisan, laporan tertulis, dan laporan khusus. Proses pengawasan kegiatan pada suatu organisasi dilaksanakan dalam berbagai tahap. Handoko (2003:363-365) mengemukakan tahapan proses pengawasan sebagai berikut:

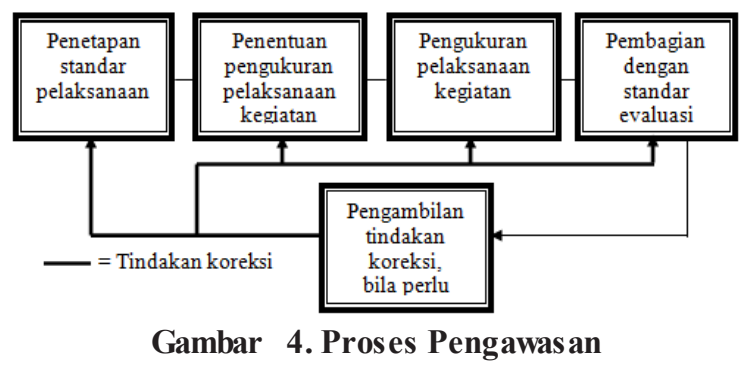

Proses pengawasan terdiri dari: penetapan standar pelaksanaan, penentuan pengukuran pelaksanaan kegiatan, pengukuran pelaksanaan kegiatan, pembandingan pelaksanaan dengan standar dan analisa penyimpangan, serta pengambilan tindakan koreksi bila diperlukan.

\section{METODE}

Penelitian ini dimaksudkan untuk memotret kondisi pengelolaan bengkel praktik SMK Teknik Pemesinan di Kabupaten Purworejo, sehingga menggunakan jenis penelitian kuantitatif dengan metode penelitian survei. Penelitian survei ini menggunakan pendekatan deskriptif kuantitatif untuk mengukur kualitas pengelolaan bengkel praktik SMK Teknik Pemesinan di Kabupaten Purworejo.

Penelitian ini dilaksanakan di SMK se Kabupaten Purworejo yang mempunyai kompetensi keahlian Teknik Pemesinan. SMK Teknik Pemesinan di Kabupaten Purworejo terdiri dari tujuh SMK yaitu: SMK N 1 Purworejo, SMK Pembaharuan Purworejo, SMK TKM Teknik Purworejo, SMK Pancasila 1 Kutoarjo, SMK PN 2 Purworejo, SMK YPT Purworejo, dan SMK Institut Indonesia Kutoarjo. Waktu penelitian survei ini dilaksanakan pada tanggal 1 April 2014 sampai dengan 30 April 2014.

Populasi pada penelitian ini adalah SMK kompetensi keahlian Teknik Pemesinan di 
Kabupaten Purworejo. Objek pada penelitian ini adalah bengkel praktik Teknik Pemesinan, sedangkan subjek pada penelitian ini adalah guru praktik Teknik Pemesinan, dimana guru praktik Teknik Pemesinan dijadikan sebagai respoden penelitian. Alasan guru praktik Teknik Pemesinan dijadikan sebagai responden pada penelitian ini adalah guru praktik Teknik Pemesinan merupakan pengelola bengkel praktik Teknik Pemesinan sehingga guru praktik Teknik Pemesinan terlibat secara langsung dalam pengelolaan bengkel praktik Teknik Pemesinan. Daftar nama SMK kompetensi keahlian Teknik Pemesinan di Kabupaten Purworejo yang menjadi populasi dan jumlah guru praktik Teknik Pemesinan yang digunakan sebagai responden pada penelitian ini adalah sebagai berikut:

Tabel 1. Daftar SMK Kompetensi Keahlian Teknik Pemesinan dan Jumlah Guru Praktik Teknik Pemesinan di Kabupaten Purworejo

\begin{tabular}{clc}
\hline No & \multicolumn{1}{c}{ Nama sekolah } & $\begin{array}{c}\text { Jumlah } \\
\text { responden }\end{array}$ \\
\hline 1 & SMK N 1 Purworejo & 11 \\
2 & SMK Pembaharuan & 9 \\
3 & SMK TKM Teknik & 6 \\
4 & SMK Pancasila 1 & 3 \\
5 & SMK PN 2 & 7 \\
6 & SMK YPT & 2 \\
7 & SMK Institut Indonesia & 3 \\
\hline & Total & 41 \\
\hline
\end{tabular}

Teknik pengambilan sampel pada penelitian ini menggunakan teknik random sampling yaitu teknik penentuan sampel secara acak terhadap semua anggota populasi. Ukuran pengambilan sampel dihitung dengan rumus Krejcie dan Morgan yaitu:

$$
S=\frac{\lambda^{2} \cdot N \cdot P \cdot Q}{d^{2}(N-1)+\lambda^{2} \cdot P \cdot Q}
$$

dimana $S=$ banyaknya sampel, $N=$ jumlah anggota populasi yakni 41 guru praktik Teknik Pemesinan, $P$ dan $Q=0,5$ sebagai konstanta untuk menghasilkan ukuran sampel maksimum, $d=0,05$ yaitu tingkat kesalahan yang diperbolehkan, dan $\lambda^{2}=3,841$ yaitu nilai dari tabel. Berdasarkan rumus tersebut, populasi dengan jumlah 41 responden maka besarnya sampel yang diperlukan adalah 37 responden.

Teknik pengumpulan data pada penelitian ini menggunakan kuisioner sebagai sumber data utama serta didukung wawancara dan observasi sebagai pendukung data kuisioner. Kuisioner digunakan untuk memperoleh data secara obyektif yakni berupa daftar pernyataan yang harus dijawab oleh responden. Kuisioner ditujukan kepada guru praktik SMK Teknik Pemesinan di Kabupaten Purworejo. Pada penelitian survei ini, wawancara digunakan untuk melengkapi data pembahasan hasil penelitian. Wawancara ditujukan kepada kepala kompetensi keahlian atau kepala bengkel Teknik Pemesinan. Wawancara dalam penelitian ini digunakan untuk mengetahui hal-hal yang lebih mendalam tentang pengelolaan bengkel praktik Teknik Pemesinan dan fenomena-fenomena yang terjadi. Observasi dilakukan oleh peneliti dengan cara melakukan pengamatan di bengkel praktik Teknik Pemesinan menggunakan lembar observasi. Data hasil observasi digunakan untuk melengkapi data pembahasan hasil penelitian. Kegiatan observasi bertujuan untuk melihat kelengkapan mesin dan area pendukung pada bengkel praktik Teknik Pemesinan.

Instrumen pengumpulan data dalam penelitian ini menggunakan kuisioner, pedoman wawancara, dan lembar observasi. Kuisioner dikembangkan berdasarkan variabel penelitian yaitu pengelolaan bengkel praktik SMK Teknik Pemesinan yang meliputi: perencanaan, pengorganisasian, pelaksanaan, dan pengawasan. Pernyataan kuisioner disusun dan dikembangkan berdasarkan indikator pada variabel penelitian dengan empat pilihan jawaban yang disediakan. Jenis kuisioner yang digunakan adalah kuisioner tertutup, dimana responden tinggal memberikan tanda check list $(\sqrt{ })$ pada lembar kuisioner. Pedoman wawancara disusun untuk mempermudah peneliti dalam melakukan tanya jawab mengenai pendapat dan tanggapan 
dari kepala kompetensi keahlian atau kepala bengkel Teknik Pemesinan. Pedoman wawancara yang digunakan berisi tentang proses pengelolaan bengkel praktik Teknik Pemesinan yang mencakup: perencanaan, pengorganisasian, pelaksanaan, dan pengawasan. Lembar observasi digunakan untuk melakukan pengamatan di bengkel praktik Teknik Pemesinan. Lembar observasi disusun berdasarkan aspek kelengkapan mesin dan area pendukung pada bengkel praktik Teknik Pemesinan. Lembar observasi yang digunakan berisi tentang: (1) kelengkapan mesin pada bengkel praktik SMK Teknik Pemesinan; (2) area pendukung bengkel praktik Teknik Pemesinan.

Teknik analisis data hasil kuisioner pengelolaan bengkel praktik SMK Teknik Pemesinan di Kabupaten Purworejo menggunakan statistik deskriptif. Statistik deskriptif yang digunakan untuk menggambarkan kondisi variabel yang diteliti yakni pengelolaan bengkel praktik SMK Teknik Pemesinan yang meliputi: perencanaan, pengorganisasian, pelaksanaan, dan pengawasan dengan menggunakan grafik dan tabel yang menampilkan mean pada setiap indikator. Hasil rerata skor kuisioner ditafsirkan untuk mengetahui kualitas indikator yang diukur. Penafsiran skor kuisioner pada penelitian ini berdasarkan daftar distribusi skor berikut:

Tabel 2. Rambu-Rambu Penafsiran Skor Kuisioner

\begin{tabular}{cccc}
\hline \multicolumn{3}{c}{ Mean } & Interpretasi \\
\hline 3,41 & - & 4,00 & Sangat baik \\
2,81 & - & 3,40 & Baik \\
2,21 & - & 2,80 & Kurang baik \\
1,61 & - & 2,20 & Tidak baik \\
1,00 & - & 1,60 & Sangat tidak baik \\
\hline \multicolumn{3}{c}{ Firdausi dan Barnawi(2012: 113) }
\end{tabular}

Hasil wawancara dianalisis secara deskriptif untuk melengkapi data penelitian. Data hasil wawancara digunakan pada pembahasan hasil penelitian untuk lebih memperkuat dan memperdalam data hasil penelitian yang didapat melalui kuisioner. Data hasil observasi dianalisis secara deskriptif yang berisi tentang kelengkapan mesin dan area pendukung bengkel praktik Teknik Pemesinan. Hasil observasi berfungsi sebagai pelengkap data penelitian sehingga dapat memperkuat hasil penelitian.

\section{HASIL DAN PEMBAHASAN}

Pengelolaan bengkel praktik SMK Teknik Pemesinan di Kabupaten Purworejo termasuk dalam kategori baik. Proses pengelolaan bengkel praktik terdiri dari empat tahapan yakni perencanaan, pengorganisasian, pelaksanaan, dan pengawasan. Adapun hasil survei pengelolaan bengkel praktik SMK Teknik Pemesinan di Kabupaten Purworejo tercermin pada gambar berikut:

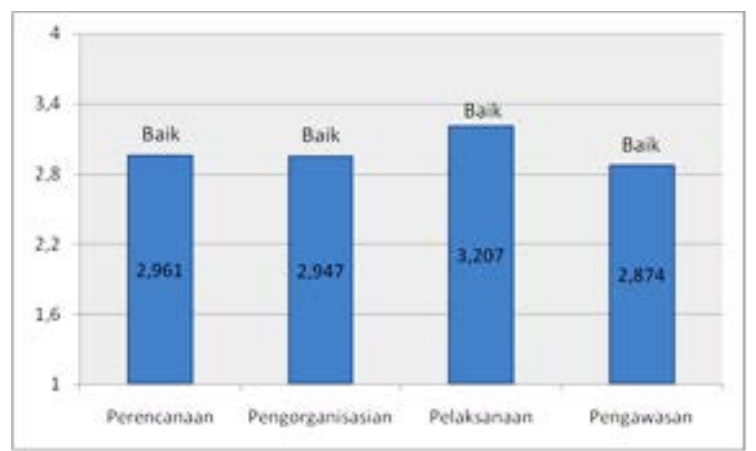

Gambar 5. Hasil Survei Pengelolaan Bengkel

Berdasarkan gambar 5 dapat diketahui bahwa pengelolaan bengkel praktik Teknik Pemesinan di Kabupaten Purworejo mempunyai: kualitas perencanaan yang baik dengan mean 2,961, kualitas pengorganisasian yang baik dengan mean 2,947, kualitas pelaksanaan yang baik dengan mean 3,207, dan kualitas pengawasan yang baik dengan mean 2,874 .

Pengelolaan bengkel praktik Teknik Pemesinan di Kabupaten Purworejo mempunyai kualitas yang baik, akan tetapi terdapat indikator yang termasuk dalam kategori kurang baik. Indikator-indikator yang kurang baik dapat menjadi kelemahan dalam pengelolaan bengkel praktik Teknik Pemesinan. Berikut ini rincian pembahasan pengelolaan bengkel praktik SMK Teknik Pemesinan di Kabupaten Purworejo: 
Perencanaan Pengelolaan Bengkel Praktik Teknik Pemesinan

Perencanaan (planning) pengelolaan bengkel praktik ditinjau dari empat indikator yakni: penetapan tujuan, perumusan keadaan saat ini, pengidentifikasian kemudahan dan hambatan, serta pengembangan serangkaian kegiatan. Hasil survei perencanaan pengelolaan bengkel praktik SMK Teknik Pemesinan di Kabupaten Purworejo tercermin pada gambar berikut ini:

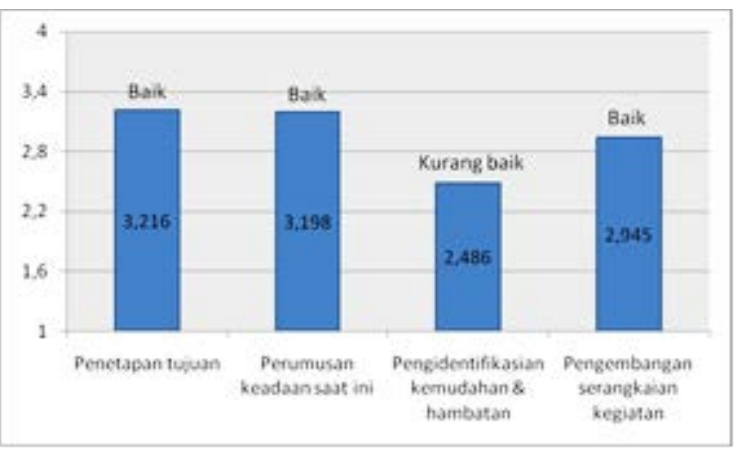

Gambar 6. Perencanaan Pengelolaan Bengkel Praktik

Berdasarkan gambar 6 dapat diketahui bahwa bengkel praktik SMK Teknik Pemesinan di Kabupaten Purworejo menetapkan tujuan termasuk dalam kategori baik dengan mean 3,216, merumuskan keadaan saat ini termasuk dalam kategori baik dengan mean 3,198, mengidentifikasi kemudahan dan hambatan termasuk dalam kategori kurang baik dengan mean 2,486, serta mengembangkan serangkaian kegiatan termasuk dalam kategori baik dengan mean 2,945.

Penetapan tujuan pada perencanaan bengkel praktik SMK Teknik Pemesinan di Kabupaten Purworejo termasuk dalam kategori baik. Bengkel praktik SMK Teknik Pemesinan di Kabupaten Purworejo pada umumnya mempunyai visi dan misi yang digunakan sebagai pedoman untuk mencapai tujuan. Rumusan visi dan misi bengkel praktik Teknik Pemesinan pada umumnya terpasang di area bengkel praktik. Berdasarkan hasil wawancara, rumusan visi dan misi yang digunakan oleh organisasi bengkel praktik Teknik Pemesinan terdapat dua jenis yakni: (1) bengkel praktik
Teknik Pemesinan mempunyai visi dan misi secara mandiri; (2) bengkel praktik Teknik Pemesinan mengikuti visi dan misi sekolah. Pendayagunaan sumber daya bengkel praktik akan efektif dan efisien apabila bengkel praktik mempunyai visi dan misi secara mandiri karena dapat disesuaikan dengan karakteristik sumber daya yang dimiliki oleh bengkel praktik, sedangkan bengkel praktik mengikuti visi dan misi sekolah kurang efektif dan efisien karena masih bersifat umum dari berbagai kompetensi keahlian di sekolah, sehingga belum tentu sesuai apabila diterapkan di bengkel praktik Teknik Pemesinan.

Perumusan keadaan saat ini pada perencanaan bengkel praktik Teknik Pemesinan di Kabupaten Purworejo termasuk dalam kategori baik. Berdasarkan hasil wawancara: (1) fasilitas bengkel praktik Teknik Pemesinan pada umumnya diinventaris setiap tahun pelajaran yakni awal tahun pelajaran; (2) data hasil inventaris alat atau mesin dan job sheet dari guru praktik pemesinan pada umumnya digunakan untuk pedoman dalam pengadaan alat atau mesin; (3) berdasarkan data kebutuhan alat dan bahan praktik disusun perencanaan anggaran belanja kebutuhan bengkel praktik. Kelemahan bengkel praktik SMK Teknik Pemesinan di Kabupaten Purworejo adalah bengkel praktik Teknik Pemesinan tidak mempunyai badan keuangan secara mandiri dan menginduk badan keuangan sekolah, sehingga realisasi pengadaan kebutuhan bengkel praktik Teknik Pemesinan tidak sesuai dengan proposal yang diajukan. Perumusan keadaan bengkel praktik lebih maksimal apabila bengkel praktik mempunyai badan keuangan secara mandiri, karena penyusunan rancangan anggaran belanja kebutuhan bengkel praktik dapat disesuaikan dengan dana yang dimiliki oleh bengkel praktik.

Pengidentifikasian kemudahan dan hambatan pada perencanaan bengkel praktik SMK Teknik Pemesinan di Kabupaten Purworejo termasuk dalam kategori kurang baik. Permasalahan bengkel praktik Teknik Pemesinan yang kemungkinan dapat terjadi, tidak diidentifikasi untuk mencari solusi 
masalah tersebut. Berdasarkan hasil wawancara, sistem yang diterapkan adalah ketika terjadi permasalahan baru dicarikan solusi untuk mengatasi masalah tersebut. Masalah yang timbul di bengkel praktik Teknik Pemesinan seperti: jumlah mesin yang tidak seimbang dengan jumlah siswa, kerusakan mesin, dan daya listrik bengkel praktik akan mengganggu pelayanan bengkel praktik terhadap pengguna bengkel praktik. Oleh karena itu, bengkel praktik Teknik Pemesinan sebaiknya menerapkan analisis SWOT untuk mengidentifikasi potensi masalah yang akan terjadi dan berupaya mencari alternatif solusi pemecahan masalah untuk meningkatkan kualitas pelayanan bengkel praktik.

Pengembangan kegiatan bengkel praktik SMK Teknik Pemesinan termasuk dalam kategori baik. Pengembangan serangkaian kegiatan terdiri dari enam aspek yaitu: (1) perincian kegiatan; (2) lokasi fisik bengkel praktik; (3) fasilitas yang mencakup alat/mesin, bahan praktik, pemeliharaan alat/ mesin, dan keselamatan kerja; (4) sumber daya manusia; (5) jadwal; dan (6) penganggaran. Perincian kegiatan pada perencanaan bengkel praktik Teknik Pemesinan di Kabupaten Purworejo termasuk dalam kategori baik, lokasi fisik bengkel praktik SMK Teknik Pemesinan di Kabupaten Purworejo termasuk dalam kategori baik, fasilitas bengkel praktik SMK Teknik Pemesinan di Kabupaten Purworejo termasuk dalam kategori baik, sumber daya manusia pada bengkel praktik SMK Teknik Pemesinan di Kabupaten Purworejo termasuk dalam kategori kurang baik, jadwal kegiatan di bengkel praktik SMK Teknik Pemesinan di Kabupaten Purworejo termasuk dalam kategori baik, dan penganggaran bengkel praktik SMK Teknik Pemesinan di Kabupaten Purworejo termasuk dalam kategori baik.

\section{Pengorganisasian Pengelolaan Bengkel Praktik Teknik Pemesinan}

Pengorganisasian (organizing) pengelolaan bengkel praktik ditinjau dari empat indikator yakni struktur organisasi, perincian seluruh pekerjaan, pembagian beban kerja, dan koordinasi. Hasil survei pengorganisasian pengelolaan bengkel praktik SMK Teknik Pemesinan di Kabupaten Purworejo tercermin pada gambar berikut ini:

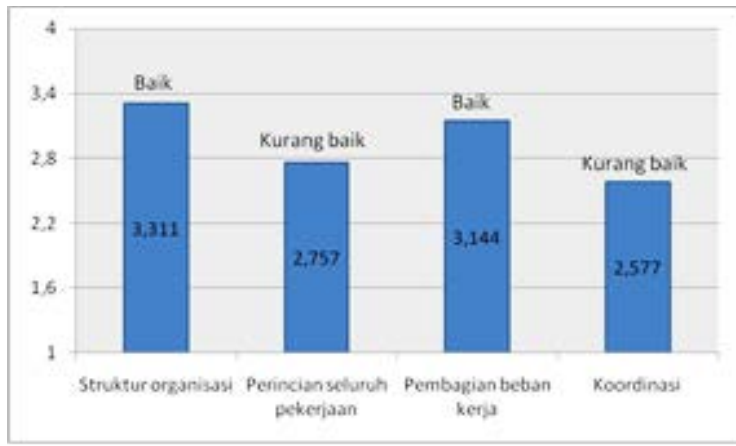

Gambar 7. Pengorganisasian Pengelolaan Bengkel Praktik

Berdasarkan gambar 7 dapat diketahui bahwa pada umumnya bengkel praktik SMK Teknik Pemesinan di Kabupaten Purworejo mempunyai struktur organisasi termasuk dalam kategori baik dengan mean 3,311, perincian seluruh pekerjaan termasuk dalam kategori kurang baik dengan mean 2,757, pembagian beban kerja termasuk dalam kategori baik dengan mean 3,144, dan koordinasi termasuk dalam kategori kurang baik dengan mean 2,577.

Struktur organisasi pada pengorganisasian bengkel praktik SMK Teknik Pemesinan di Kabupaten Purworejo termasuk dalam kategori baik. Berdasarkan hasil wawancara:(1) bagan struktur organisasi terpasang di area bengkel praktik Teknik Pemesinan; (2) penetapan struktur organisasi bengkel praktik Teknik Pemesinan sebagian besar ditunjuk secara langsung oleh pimpinan sekolah dan tidak didasarkan oleh pertimbangan rapat anggota organisasi bengkel praktik Teknik Pemesinan. Struktur organisasi bengkel praktik dapat bekerja secara maksimal apabila susunan personel tepat sesuai kompetensi yang dimiliki serta disetujui oleh seluruh anggota organisasi untuk menciptakan kinerja organisasi yang efektif dan efisien.

Perincian pekerjaan pada pengorganisasian bengkel praktik SMK Teknik Pemesinan 
di Kabupaten Purworejo termasuk dalam kategori kurang baik. Struktur organisasi bengkel praktik SMK Teknik Pemesinan di Kabupaten Purworejo sebagian besar tidak dilengkapi dengan perincian tugas pada setiap jabatan organisasi. Berdasarkan hasil wawancara, tugas masing-masing personel organisasi bengkel praktik sebagian besar kurang disosialisasikan dengan baik. Perincian seluruh pekerjaan pada struktur organisasi bengkel praktik bertujuan untuk mempermudah pengawasan kinerja anggota organisasi baik dilihat dari segi wewenang dan tanggung jawab sesuai jabatan pada struktur organisasi. Apabila struktur organisasi tidak dilengkapi dengan perincian pekerjaan, maka pengawasan kinerja organisasi tidak dapat dilakukan secara maksimal karena wewenang dan tanggung jawab jabatan struktural organisasi tidak tertuang secara jelas.

Pembagian beban kerja pada pengorganisasian bengkel praktik SMK Teknik Pemesinan di Kabupaten Purworejo termasuk dalam kategori baik. Pembagian beban kerja yang baik karena penempatan personel pada struktur organisasi bengkel praktik SMK Teknik Pemesinan di Kabupaten Purworejo mempertimbangkan faktor kemampuan yang dimiliki oleh masing-masing anggota organisasi, pembagian beban kerja dilakukan secara proporsional yakni tidak terlalu berat dan tidak terlalu ringan, serta dapat mempermudah proses pengawasan. Berdasarkan hasil wawancara, strategi pembagian beban kerja pada organisasi bengkel praktik adalah dalam bentuk surat tugas dan dilampiri uraian pembagian tugas yang ditandatangani oleh kepala sekolah pada awal tahun pelajaran. Diharapkan pembagian tugas melalui surat tugas di awal tahun pelajaran dapat membagi pekerjaan organisasi bengkel praktik secara adil, proporsional, dan dapat memenuhi tuntutan beban jam mengajar terutama untuk kepentingan sertifikasi guru.

Kegiatan koordinasi pada pengorganisasian bengkel praktik SMK Teknik Pemesinan di Kabupaten Purworejo termasuk dalam kategori kurang baik. Berdasarkan hasil wawancara: (1) intensitas pertemuan formal masih kurang pertemuan formal hanya dilaksanakan pada awal tahun pelajaran dan sebelum pelaksanaan ujian kompetensi keahlian, bahkan tidak dilakukan koordinasi melalui pertemuan formal; (2) pertemuan non formal organisasi bengkel praktik Teknik Pemesinan dilakukan melalui komunikasi lisan antar anggota organisasi terkait dengan program bengkel praktik; (3) sebagian besar organisasi bengkel praktik Teknik Pemesinan tidak mempunyai buku pedoman organisasi yang dapat mempermudah dalam koordinasi. Koordinasi yang baik seharusnya organisasi bengkel praktik secara rutin dan terjadwal mengadakan pertemuan resmi untuk membahas program kerja atau pengembangan bengkel praktik, mengadakan pertemuan informal untuk menjalin hubungan baik antar anggota organisasi, dan mempunyai buku pedoman organisasi yang berisi program kerja dan uraian tugas untuk mempermudah koordinasi.

\section{Pelaksanaan Pengelolaan Bengkel Praktik Teknik Pemesinan}

Pelaksanaan (actuating) pengelolaan bengkel praktik ditinjau dari tiga indikator yaitu: komunikasi organisasi, pemberian motivasi, dan kepemimpinan organisasi. Hasil survei pelaksanaan pengelolaan bengkel praktik SMK Teknik Pemesinan di Kabupaten Purworejo tercermin pada gambar berikut ini:

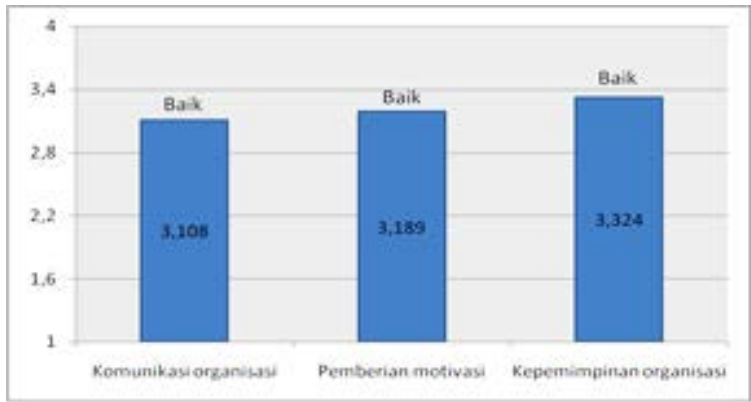

Gambar 8. Pelaksanaan Pengelolaan Bengkel Praktik

SMK Teknik Pemesinan di Kabupaten Purworejo termasuk dalam kategori baik dengan mean 3,108, pemberian motivasi kepada 
seluruh anggota organisasi termasuk dalam kategori baik dengan mean 3,189, dan kepemimpinan organisasi pada bengkel praktik SMK Teknik Pemesinan di Kabupaten Purworejo termasuk dalam kategori baik dengan mean 3,324.

Komunikasi pada pelaksanaan pengelolaan organisasi bengkel praktik SMK Teknik Pemesinan di Kabupaten Purworejo termasuk dalam kategori baik. Berdasarkan hasil wawancara, komunikasi antar anggota organisasi dapat berjalan dengan baik tanpa adanya permasalahan. Komunikasi organisasi meliputi: komunikasi pimpinan memberikan perintah kepada anggota organisasi, komunikasi anggota organisasi menyampaikan laporan kepada pimpinan, komunikasi seluruh anggota organisasi untuk saling menyampaikan informasi, dan komunikasi pimpinan memberikan saran kepada anggota organisasi sebagian besar dapat berjalan dengan baik.

Pemberian motivasi pada pelaksanaan pengelolaan organisasi bengkel praktik SMK Teknik Pemesinan di Kabupaten Purworejo termasuk dalam kategori baik. Berdasarkan hasil wawancara pemberian motivasi berupa: (1) seluruh anggota organisasi mendapatkan perhatian dengan baik; (2) menumbuhkan rasa kebersamaan dan membina hubungan baik antar anggota organisasi; (3) menggunakan pendekatan untuk menciptakan suasana harmonis. Pemberian motivasi yang baik dilakukan oleh ketua organisasi bengkel praktik yakni memberikan perhatian pada anggota organisasi bengkel praktik, sehingga anggota organisasi bengkel praktik Teknik Pemesinan merasa berguna dan penting karena diberikan tanggung jawab penuh untuk melaksanakan tugas demi tercapainya prestasi kerja yang baik.

Kepemimpinan organisasi pada pelaksanaan pengelolaan organisasi bengkel praktik SMK Teknik Pemesinan di Kabupaten Purworejo termasuk dalam kategori baik. Berdasarkan hasil wawancara: (1) ketua organisasi memberikan kepercayaan dan menghargai seluruh anggota organisasi; (2) ketua organisasi mengajak anggota orga- nisasi bermusyawarah untuk mengatasi permasalahan; (3) ketua organisasi membuat keputusan berdasarkan pertimbangan rapat, saling membantu, dan menumbuhkan kesadaran unutk bekerja dengan baik; (4) ketua organisasi merangkul semua anggota organisasi sehingga tercipta hubungan kekeluargaan yang baik. Kepemimpinan yang baik dapat dicapai melalui upaya ketua organisasi bengkel praktik Teknik Pemesinan dapat mengambil keputusan secara bijak, menempatkan seseorang pada struktur organisasi dengan tepat, menjaga suasana keharmonisan, selalu menyampaikan informasi tentang program kerja dengan baik, ketua organisasi lebih memahami permasalahan bengkel praktik dibandingkan anggota organisasi yang lain, memberikan saran dalam penyelesaian pekerjaan apabila ada yang mengalami kesulitan, dan melibatkan anggota organisasi dalam membuat keputusan.

\section{Pengawasan Pengelolaan Bengkel Praktik Teknik Pemesinan}

Pengawasan (controlling) pengelolaan bengkel praktik ditinjau dari sembilan indikator yaitu: waktu pengawasan, objek pengawasan, subjek pengawasan, peninjauan, pelaporan, penetapan standar pelaksanaan, pengukuran pelaksanaan kegiatan, pembandingan pelaksanaan kegiatan dengan standar dan analisa penyimpangan, serta pengambilan tindakan koreksi bila diperlukan. Hasil survei pengawasan pengelolaan bengkel praktik SMK Teknik Pemesinan di Kabupaten Purworejo tercermin pada gambar berikut ini:

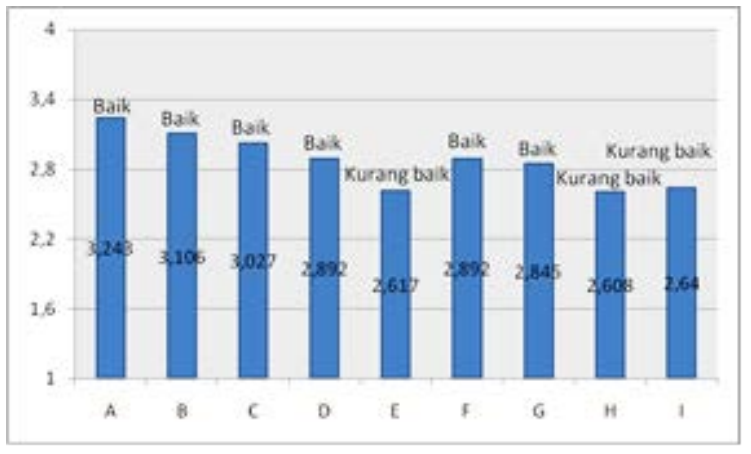

Gambar 9. Pengawasan Pengelolaan Bengkel Praktik 
Berdasarkan gambar 9 dapat diketahui bahwa waktu pengawasan termasuk dalam kategori baik dengan mean 3,243, objek pengawasan termasuk dalam kategori baik dengan mean 3,106, subjek pengawasan termasuk dalam kategori baik dengan mean 3,027 , peninjauan termasuk dalam kategori baik dengan mean 2,892, pelaporan termasuk dalam kategori kurang baik dengan mean 2,617, penetapan standar pelaksanaan termasuk dalam kategori baik dengan mean 2,892, pengukuran pelaksanaan kegiatan termasuk dalam kategori baik dengan mean 2,845, pembandingan pelaksanaan kegiatan dengan standar dan analisa penyimpangan termasuk dalam kategori kurang baik dengan mean 2,608, serta pengambilan tindakan koreksi termasuk dalam kategori kurang baik dengan mean 2,640.

Waktu pengawasan pada pengawasan bengkel praktik SMK Teknik Pemesinan di Kabupaten Purworejo termasuk dalam kategori baik. Pada umumnya kegiatan bengkel praktik diawasi secara preventif yaitu pada saat kegiatan sedang dilaksanakan. Berdasarkan hasil wawancara, pengawasan dilakukan oleh guru dan teknisi kepada siswa pada saat pembelajaran praktik dilihat dari prosedur kerja dan keselamatan kerja. Tujuan pengawasan secara preventif adalah untuk mencegah terjadinya kesalahan, sehingga pekerjaan yang dilaksanakan dapat berhasil sesuai dengan rencana.

Pengawasan terhadap objek yang harus diawasi pada bengkel praktik SMK Teknik Pemesinan di Kabupaten Purworejo termasuk dalam kategori baik. Objek pengawasan dilihat dari: pengawasan alat/mesin, pengawasan bahan praktik, pengawasan kinerja organisasi, dan pengawasan penggunaan bengkel praktik. Pengawasan alat/mesin termasuk dalam kategori baik, pengawasan bahan praktik termasuk dalam kategori baik, pengawasan kinerja anggota organisasi termasuk dalam kategori baik, dan pengawasan penggunaan bengkel praktik termasuk dalam kategori baik.

Subjek pengawasan pada pengawasan bengkel praktik SMK Teknik Pemesinan di
Kabupaten Purworejo termasuk dalam kategori baik. Bengkel praktik SMK Teknik Pemesinan diawasi oleh pengawas intern dan pengawas ekstern. Berdasarkan hasil wawancara: (1) kegiatan bengkel praktik diawasi secara periodik oleh pengawas intern seperti: ketua kompetensi keahlian, kepala bengkel, dan kepala sekolah; (2) pengawasan ekstern bengkel praktik Teknik Pemesinan yakni oleh pengawas sekolah. Pengawasan bengkel praktik bertujuan untuk memastikan bahwa organisasi bengkel praktik dapat menjalankan fungsinya dengan baik sebagai tempat mengembangkan keterampilan siswa.

Kegiatan peninjauan pada pengawasan bengkel praktik SMK Teknik Pemesinan di Kabupaten Purworejo termasuk dalam kategori baik. Peninjauan bengkel praktik Teknik Pemesinan dilakukan oleh ketua organisasi bengkel praktik. Berdasarkan hasil wawancara: (1) ketua kompetensi keahlian atau kepala bengkel melakukan peninjauan langsung mengenai kondisi bengkel praktik Teknik Pemesinan secara berkala; (2) peninjauan langsung juga dilakukan oleh pengawas sekolah pada saat verifikasi alat/mesin sebelum pelaksanaan ujian kompetensi keahlian, akan tetapi intensitasnya masih kurang yakni satu tahun pelajaran sekali. Oleh karena itu, kegiatan peninjauan mempunyai peranan yang sangat penting untuk mengetahui permasalahan yang ada di lapangan dengan harapan dapat mencari solusi untuk mengatasi permasalahan yang terjadi di bengkel praktik.

Pelaporan pada pengawasan bengkel praktik SMK Teknik Pemesinan di Kabupaten Purworejo termasuk dalam kategori kurang baik. Sistem pelaporan tentang kegiatan atau kondisi bengkel praktik SMK Teknik Pemesinan di Kabupaten Purworejo kurang berjalan dengan baik. Berdasarkan hasil wawancara, pelaporan pada bengkel praktik meliputi: laporan hasil belajar siswa, laporan perawatan atau perbaikan mesin, dan laporan pengadaan alat atau bahan. Sebagian besar anggota organisasi melaporkan hasil pekerjaan secara lisan kepada ketua organisasi berjalan 
dengan baik. Laporan tertulis tentang: laporan informatif untuk melaporkan kondisi fasilitas bengkel, laporan pertanggungjawaban untuk melaporkan pekerjaan yang telah dilaksanakan, dan laporan kelayakan untuk menilai kondisi alat/mesin sebagian besar kurang berjalan dengan baik, sedangkan laporan rekomendasi apabila terjadi kerusakan alat/mesin untuk dilakukan perbaikan sudah berjalan dengan baik. Sistem pelaporan pada bengkel praktik harus berjalan dengan baik yakni laporan lisan atau laporan tertulis yang meliputi laporan informatif, laporan rekomendasi, laporan pertanggungjawaban, dan laporan kelayakan supaya kondisi fasilitas bengkel dapat dievaluasi untuk meningkatkan kualitas pengelolaan bengkel paktik.

Penetapan standar pelaksanaan kegiatan bengkel praktik SMK Teknik Pemesinan di Kabupaten Purworejo termasuk dalam kategori baik. Sebagian besar bengkel praktik mempunyai standar atau kriteria keberhasilan yang berfungsi sebagai patokan penilaian kegiatan bengkel praktik dengan baik. Berdasarkan hasil wawanacara kriteria keberhasilan bengkel praktik yang digunakan adalah: (1) kriteria ketuntasan minimal sesuai dengan kebijakan sekolah untuk menilai hasil belajar siswa; (2) menetapkan persentase jumlah siswa dapat lulus uji kompetensi; (3) menetapkan persentase jumlah siswa dapat menyelesaikan job praktik tepat waktu. Kelemahan dari penetapan standar pelaksanaan adalah kriteria keberhasilan kegiatan bengkel praktik sebagian besar ditetapkan oleh ketua organisasi secara langsung dan tidak melalui pertimbangan rapat antar anggota organisasi bengkel praktik Teknik Pemesinan. Kriteria keberhasilan digunakan untuk memotivasi seluruh anggota organisasi untuk bekerja dengan baik dalam rangka mencapai kriteria keberhasilan yang telah ditetapkan.

Pengukuran pelaksanaan kegiatan bengkel praktik SMK Teknik Pemesinan di Kabupaten Purworejo termasuk dalam kategori baik. Sebagian besar metode pengawasan kegiatan bengkel praktik disosialisasikan dengan baik kepada seluruh anggota organisasi bengkel praktik Teknik Pemesinan. Berdasarkan hasil wawancara pengukuran pelaksanaan kegiatan dilakukan menggunakan: (1) observasi proses pekerjaan; (2) pengujian hasil kerja; (3) laporan hasil pekerjaan. Metode pengukuran pelaksanaan kegiatan bengkel praktik harus mengkombinasikan antara metode observasi proses pekerjaan, pengujian hasil kerja, dan laporan hasil pekerjaan untuk memastikan bahwa keseluruhan pekerjaan dilakukan dengan prosedur yang benar.

Pembandingan pelaksanaan kegiatan bengkel praktik SMK Teknik Pemesinan di Kabupaten Purworejo dengan standar dan analisis penyimpangan termasuk dalam kategori kurang baik. Berdasarkan hasil wawancara, penilaian hasil pekerjaan berhubungan dengan waktu penyelesaian pekerjaan dan penyimpangan ukuran pada hasil kerja. Analisis hasil pekerjaan untuk mengetahui tingkat keberhasilan pelaksanaan kegiatan bengkel praktik belum dilakukan dengan baik dan hasil analisis yang belum mencapai standar belum dikaji untuk mengetahui penyebab ketidakberhasilan pelaksanaan kegiatan. Keberhasilan pengelolaan bengkel praktik belum diupayakan secara maksimal untuk memperoleh hasil analisis yang dapat dijadikan acuan pengelolaan pada tahun pelajaran berikutnya.

Pengambilan tindakan koreksi pada pelaksanaan kegiatan bengkel praktik SMK Teknik Pemesinan di Kabupaten Purworejo termasuk dalam kategori kurang baik. Berdasarkan hasil wawancara, tindakan koreksi dilakukan dengan memperbaiki proses pekerjaan melalui kegiatan remidi. Metode pengambilan tindakan koreksi baik itu memperbaiki pelaksanaan kegiatan ataupun kombinasi merubah kriteria keberhasilan dan memperbaiki pelaksanaan kurang berjalan dengan baik. Sebagian besar kegiatan tindak lanjut berdasarkan hasil evaluasi kurang berjalan dengan baik dan tindakan koreksi hanya dituangkan dalam administrasi evaluasi program bengkel praktik Teknik Pemesinan, 
akan tetapi proses tindak lanjut belum dilakukan secara maksimal.

\section{SIMPULAN}

Berdasarkan hasil penelitian, maka dapat ditarik kesimpulan sebagai berikut: perencanaan (planning) pengelolaan bengkel praktik SMK Teknik Pemesinan di Kabupaten Purworejo mempunyai kualitas yang baik dengan mean 2,961; (2) pengorganisasian (organizing) pengelolaan bengkel praktik SMK Teknik Pemesinan di Kabupaten Purworejo mempunyai kualitas yang baik dengan mean 2,947; (3) pelaksanaan (actuating) pengelolaan bengkel praktik SMK Teknik Pemesinan di Kabupaten Purworejo mempunyai kualitas yang baik dengan mean 3,207; (4) pengawasan (controlling) pengelolaan bengkel praktik SMK Teknik Pemesinan di Kabupaten Purworejo mempunyai kualitas yang baik dengan mean 2,874 .

Berdasarkan kesimpulan pada penelitian ini, peneliti bermaksud memberikan saran kepada pengelola bengkel praktik SMK Teknik Pemesinan di Kabupaten Purworejo yaitu sebagai berikut: (1) perencanaan (planning) pengelolaan bengkel praktik SMK Teknik Pemesinan di Kabupaten Purworejo sebaiknya lebih ditingkatkan terutama terkait dengan pengidentifikasian kemudahan dan hambatan, serta pengembangan serangkaian kegiatan; (2) pengorganisasian (organizing) pengelolaan bengkel praktik SMK Teknik Pemesinan di Kabupaten Purworejo sebaiknya lebih ditingkatkan terutama terkait dengan perincian seluruh pekerjaan dan koordinasi;

pelaksanaan (actuating) pengelolaan bengkel praktik SMK Teknik Pemesinan di Kabupaten Purworejo sebaiknya dipertahankan dan lebih ditingkatkan baik mengenai komunikasi, pemberian motivasi, dan kepemimpinan; (4) pengawasan (controlling) pengelolaan bengkel praktik SMK Teknik Pemesinan di Kabupaten Purworejo sebaiknya lebih ditingkatkan terutama terkait dengan peninjauan, pelaporan, penetapan standar pelaksanaan, pengukuran pelaksanaan kegiatan, pembandingan pelaksanaan kegiatan dengan standar dan analisa penyimpangan, serta pengambilan tindakan koreksi.

\section{DAFTAR RUJUKAN}

Aurigemma, J., et.al, 2013. Turning experiments objects: the cognitive processes involved in the design of a labon-a-chip device. Journal of Engineering Education, 102, 117-140

Brown, R.D. 1979. Industrial education facilities: a handbook for organization and management. Boston: Allyn and Bacon

CEFP. 1969. Guide for planning educational fasilities. Columbus: The Council of Educational Facility Planners

Depdiknas. 2008. Peraturan Menteri Pendidikan Nasional Republik Indonesia Nomor 40, Tahun 2008, tentang Standar Sarana dan Prasarana Sekolah Menengah Kejuruan/Madrasah Aliyah Kejuruan (SMK / MAK)

Firdausi, Arif., \& Barnawi. 2012. Profil guru SMK profesional. Yogyakarta: Ar-Ruzz Media

Handoko, T.H. 2003. Manajemen (Edisi 2). Yogyakarta: BPFE

Hasibuan, M.S.P. 2007. Manajemen dasar, pengertian, dan masalah (edisi revisi). Jakarta: PT. Bumi Aksara

Manullang, Marihot. 2006. Dasar-dasar manajemen. Yogyakarta: Gadjah Mada University Press

Pavlova, M. 2009. Technology and vocational education for sustainable development. Mt Gravatt: Griffith University. 
Pemkab Purworejo. 2012. Purworejo deklarasikan sebagai kabupaten vokasi. Diakses tanggal 3 Juni 2014 http://purworejokab.go.id/news/seputarpendidikan/1791-purworejodeklarasikan-sebagai-kabupaten-vokasi

Rochadi, L.H. 2011. Pengelolaan workshop praktek jurusan bangunan di SMK yang efektif dan efisien menuju standar bengkel di industri. Makalah disajikan dalam Workshop Pengelolaan Bengkel SMK Jawa Tengah Tahun 2011, di Semarang

Singer, S.R., Hilton, M.L., \& Schweingruber, H.A. 2006. America's lab report investigations in high school science. Washington DC: The National Academies Press

Terry, G.R. 1986. Asas-asas manajemen. (Terjemahan Winardi). Homewood: Richard D. Irwin

Terry, G.R. 1974. Principle of management $\left(6^{\text {th }}\right.$ ed.). Homewood: Richard D. Irwin

Wilson, D.H. 2010. Vocational education in high school: a future outlook. Diakses tanggal 5 Desember 2013, dari http://search.proquest.com/ docview/305244953/fulltextPDF/1422A3 $54 \mathrm{C} 2 \mathrm{C} 3 \mathrm{BEC} 5 \mathrm{~F} 57 / 1$ ? accountid $=31324$ 